\title{
Absorption and metabolism of bioactive molecules after oral consumption of cooked edible heads of Cynara scolymus L. (cultivar Violetto di Provenza) in human subjects: a pilot study
}

\author{
E. Azzini ${ }^{1}$, R. Bugianesi ${ }^{1}$, F. Romano ${ }^{1}$, D. Di Venere $^{2}$, S. Miccadei $^{3}$, A. Durazzo ${ }^{1}$, M. S. Foddai ${ }^{1}$, \\ G. Catasta ${ }^{1}$, V. Linsalata ${ }^{2}$ and G. Maiani ${ }^{1}$ * \\ ${ }^{1}$ Istituto Nazionale di Ricerca per gli Alimenti e la Nutrizione, Via Ardeatina 546, 00178 Roma, Italy \\ ${ }^{2}$ CNR - Istituto di Scienze delle Produzioni Alimentari (ISPA), Via Amendola 122/O, 70126 Bari, Italy \\ ${ }^{3}$ Istituto Regina Elena, CRS, Via delle Messi d'Oro 156, 00158 Roma, Italy \\ (Received 5 June 2006 - Revised 23 October 2006 - Accepted 22 November 2006)
}

\begin{abstract}
The current growing interest for natural antioxidants has led to a renewed scientific attention for artichoke, due not only to its nutritional value, but, overall, to its polyphenolic content, showing strong antioxidant properties. The major constituents of artichoke extracts are hydroxycinnamic acids such as chlorogenic acid, dicaffeoylquinic acids caffeic acid and ferulic acid, and flavonoids such as luteolin and apigenin glycosides. In vitro studies, using cultured rat hepatocytes, have shown its hepatoprotective functions and in vivo studies have shown the inhibition of cholesterol biosynthesis in human subjects. Several studies have shown the effect on animal models of artichoke extracts, while information on human bioavailability and metabolism of hydroxycinnamates derivatives is still lacking. Results showed a plasma maximum concentration of 6.4 (SD 1.8) ng/ml for chlorogenic acid after $1 \mathrm{~h}$ and its disappearance within $2 \mathrm{~h}(P<0.05)$. Peak plasma concentrations of 19.5 (SD6.9) ng/ml for total caffeic acid were reached within $1 \mathrm{~h}$, while ferulic acid plasma concentrations showed a biphasic profile with $6.4(\mathrm{SD} 1.5) \mathrm{ng} / \mathrm{ml}$ and $8.4(\mathrm{SD} 4.6) \mathrm{ng} / \mathrm{ml} \mathrm{within} 1 \mathrm{~h}$ and after $8 \mathrm{~h}$ respectively. We observed a significant increase of dihydrocaffeic acid and dihydroferulic acid total levels after $8 \mathrm{~h}(P<0 \cdot 05)$. No circulating plasma levels of luteolin and apigenin were present. Our study confirms the bioavailability of metabolites of hydroxycinnamic acids after ingestion of cooked edible Cynara scolymus L. (cultivar Violetto di Provenza).
\end{abstract}

Cooked artichoke heads: Absorption: Metabolism: Hydroxycinnamic acids: Human subjects

Artichoke (Cynara scolymus L.) is an ancient herbaceous perennial plant, originating from the Mediterranean area, which today is cultivated all over the world. The leaves of artichoke have been widely used in herbal medicine as a choleretic and diuretic since ancient times (Bruneton, 1995).

Several studies have demonstrated the efficiency and safety of artichoke extracts in the treatment of hepato-biliary disfunction and digestive complaints in animals (Adzet et al. 1987; Speroni et al. 2003) and in human subjects (Kraft, 1997; Kirchhoff et al. 1994). Several clinical investigations showed the ability of artichoke extract to prevent the oxidative modification of blood lipoproteins and to reduce blood cholesterol levels (Kirchhoff et al. 1994; Gebhardt, 1998, 2002; Zapolska-Downar et al. 2002; Shimoda et al. 2003). Moreover leaf extracts have been reported to show antioxidative and protective properties against hydroperoxide-induced oxidative stress in cultured rat hepatocytes (Gebhardt, 1997; Miccadei et al. 2004). Artichoke beneficial effects seem due to the biochemical constituents, mainly polyphenols (chlorogenic acid (CGA), mono- and di-caffeoylquinic acids and flavonoids such as luteolin and apigenin glycosides), sugars and inulin. The health-promoting prebiotic effects of artichoke inulin were related to the stimulation of bifidobacterial growth in the intestine (Roberfroid et al. 1998; Lopez-Molina et al. 2005). The characterization and quantification of bioactive molecules in artichoke have been studied extensively (Wang et al. 2003; Schütz et al. 2004; Zhu et al. 2004) while little is known on the bioavailability and bioactivity of these substance from natural or supplemental sources. Polyphenols are abundant micronutrients in our diet and evidence for their role in the prevention of degenerative disease is emerging. Bioavailability greatly differs from one polyphenol to another, so that the most abundant polyphenols in our diet are not necessarily those leading to the highest concentration of active metabolites on target tissues (Manach et al. 2004, 2005).

The aim of this study was to evaluate the absorption and metabolism of bioactive molecules after oral consumption of cooked edible portion of artichoke heads in human subjects.

\footnotetext{
Abbreviations: CGA, chlorogenic acid; CA, caffeic acid; DHCA, dihydrocaffeic acid; FA, ferulic acid; DHFA, dihydroferulic acid.

* Corresponding author: Dr. Giuseppe Maiani, fax +3906 51494550, email maiani@inran.it
} 


\section{Materials and methods}

\section{Chemicals and reagents}

All solvent reagents were HPLC or Optima grade; common reagents were purchased from Sigma (St Louis, MO, USA), Carlo Erba (Milan, Italy) and BDH Laboratory Supplies. (Poole, Dorset, UK) CGA, caffeic acid (CA), ferulic acid (FA), apigenin (Lyon Nord, France) and luteolin were purchased from Sigma, dihydrocaffeic acid (DHCA) from Extrasynthese (Lyon Nord, France) and dihydroferulic acid (DHFA) from AVOCADO Research Chemicals Ltd (Morecambe, Lancashire, UK).

\section{Subjects}

Five healthy non smoking subjects (two males and three females), aged 25-32 years, body weight 61.0 (SD 9.5) kg and BMI 21.5 (SD 1.5) $\mathrm{kg} / \mathrm{m}^{2}$, were recruited on the basis of their normal blood values and clinical anamnesis from the National Institute for Research on Food and Nutrition staff (INRAN, Rome).

Each subject signed an informed consent approved by the Ethical Committee of INRAN. Several studies have shown significant effects of treatment with a small number of subjects (Hollman et al. 1996; McAnlis et al. 1999; Cremin et al. 2001; Rechner et al. 2001a; Olthof et al. 2001; Bugianesi et al. 2004).

Subjects did not use any drug or vitamin supplementation. During the three days before the experimental day, subjects were asked to follow a controlled diet limiting fruit and vegetables consumption to not more than $100 \mathrm{~g} /$ day, and avoiding artichokes, carrots, tomatoes, apples, pears, peaches, cherries, strawberries, blueberries, tea, coffee, wine, beer, chocolate and all their derived products. Food consumption during the three days of wash out was surveyed by a dietitian to check the diet balance by a record and recall method.

\section{Study design}

After fasting overnight, baseline blood samples were collected from each subject. After blood collection, all subjects consumed 61.7 (SD 4.4) g edible artichoke (cultivar Violetto di Provenza), steam cooked with 5.5 (SD 0.4) g extra virgin olive oil and venous blood sample collection was repeated at $0.5,1,2,4,6$ and $8 \mathrm{~h}$ from the experimental test meal consumption.

Total energy and macronutrient content were calculated by using Food Composition Tables (National Institute for Research on Food and Nutrition, 2000). CGA, mono- and di-caffeoylquinic acids, cynarin (1,3-dicaffeoylquinic acid), luteolin-glycoside and apigenin-glycoside contents of the experimental meal are reported in Table 1.

The edible portion of artichoke heads was chosen on the basis of analysed polyphenols content of cultivar selected for the study. Artichoke heads, consumed by all participants, were collected raw and cooked in order to evaluate the polyphenol contents. Table 2 shows replicate analyses of artichoke heads both raw, and cooked as $\mathrm{mg} / 100 \mathrm{~g}$ edible portion.

\section{Artichoke analysis}

About $25 \mathrm{~g}$ raw and cooked heads of artichoke were homogenized in a $250 \mathrm{ml}$ flask by adding $150 \mathrm{ml} \mathrm{MeOH}$ and were
Table 1. Polyphenol contents of the experimental meal.

\begin{tabular}{lrr}
$\begin{array}{l}\text { (Mean values and standard deviations for } \\
\text { replicate analyses on cooked artichoke) }\end{array}$ \\
\hline Polyphenol content (mg) & Mean & SD \\
\hline Monocaffeoylquinic acids & 41.2 & 0.4 \\
Chlorogenic acid & 189.7 & 6.3 \\
Cynarin & 11.3 & 0.3 \\
Dicaffeoylquinic acids & 244.5 & 5.2 \\
Luteolin-glycoside & 4.9 & 0.2 \\
Apigenin-glycoside & 6.0 & 0.5 \\
\hline
\end{tabular}

extracted by stirring, heating and refluxing for $90 \mathrm{~min}$ with regular swirling.

The solutions obtained were filtered and the residues were extracted twice after adding $100 \mathrm{ml} \mathrm{MeOH}$ by stirring, heating and refluxing for $30 \mathrm{~min}$ with regular swirling. Pooled extracts were evaporated by rotavapor and reconstituted by adding $100 \mathrm{ml} \mathrm{H}_{2} \mathrm{O}-\mathrm{MeOH}(1: 1$, v/v).

The determination of polyphenols in artichoke heads was carried out in agreement with Di Venere et al. (2005) and the quantification was performed by HPLC using a liquid chromatograph equipped with binary gradient pump and spectrophotometric photodiode array detector (Agilent Technologies S.P.A., Milan, Italy). The Hewlett Packard Chem Station (Rev. A. 06.03) software was used for spectra and data processing. An analytical Phenomenex (Torrance, CA, USA) Ultracarb 5 ODS (30) column $(4.6 \times 250 \mathrm{~mm})$ was used for peak separation and the elution profile was reported by Lattanzio \& Van Sumere (1987). The method recovery performance was assayed by addition of suitable amounts of standards prior to the extraction of the solid samples. Recovery rates of the method were found to be $>85 \%$ for caffeoylquinic acids as well as luteolin and apigenin glycosides.

The method precision was assayed by three series of extractions, each performed in triplicate using one different artichoke head. The percentage relative standard deviation for the normalized peak areas of all evaluated compounds was found to be $<5 \%$ (data not shown).

\section{Plasma samples}

Blood samples were drawn into vacutainers containing EDTA as anticoagulant. Blood samples were centrifuged at $3600 \mathrm{~g}$ for $10 \mathrm{~min}$ at $4^{\circ} \mathrm{C}$, plasma was separated and stored at $-80^{\circ} \mathrm{C}$

Table 2. Selected polyphenols analysis on raw and cooked Cynara scolymus $L$ (cultivar Violetto di Provenza) heads.

(Mean values and standard deviations)

\begin{tabular}{|c|c|c|c|c|}
\hline \multirow{2}{*}{$\begin{array}{l}\text { Polyphenol } \\
\text { (mg/100 g edible portion) }\end{array}$} & \multicolumn{2}{|c|}{ Raw } & \multicolumn{2}{|c|}{ Cooked } \\
\hline & Mean & SD & Mean & SD \\
\hline Chlorogenic acid & $276 \cdot 1$ & 30.9 & 307.5 & $10 \cdot 3$ \\
\hline Total monocaffeoylquinic acids & $16 \cdot 9$ & $1 \cdot 0$ & $66 \cdot 7$ & 0.6 \\
\hline Cynarin & 0.0 & 0.0 & $18 \cdot 3$ & 0.5 \\
\hline Total dicaffeoylquinic acids & $309 \cdot 7$ & $21 \cdot 8$ & $396 \cdot 3$ & $8 \cdot 4$ \\
\hline Luteolin-glycoside & 7.5 & 0.2 & $7 \cdot 9$ & 0.3 \\
\hline Apigenin-glycoside & $10 \cdot 0$ & 0.7 & $9 \cdot 8$ & $0 \cdot 1$ \\
\hline
\end{tabular}


Table 3. Pharmacokinetic parameters of total chlorogenic acid (CGA), caffeic acid (CA), ferulic acid (FA), dihydrocaffeic acid (DHCA) and dihydroferulic acid (DHFA) absorption in human plasma after consumption of cooked Cynara scolymus L. (cultivar Violetto di Provenza) heads

(Mean values and standard deviations)

\begin{tabular}{|c|c|c|c|c|c|c|c|c|c|c|}
\hline \multirow[b]{2}{*}{ Parameter } & \multicolumn{2}{|c|}{ CGA } & \multicolumn{2}{|c|}{ DHCA } & \multicolumn{2}{|c|}{$\mathrm{CA}$} & \multicolumn{2}{|c|}{ DHFA } & \multicolumn{2}{|c|}{ FA } \\
\hline & Mean & SD & Mean & SD & Mean & SD & Mean & SD & Mean & SD \\
\hline $\mathrm{C}_{\max }(\mathrm{ng} / \mathrm{ml})$ & $6 \cdot 4$ & 1.7 & $12 \cdot 1$ & $7 \cdot 2$ & $19 \cdot 5$ & 6.9 & $21 \cdot 8$ & 9.2 & 8.4 & 4.6 \\
\hline $\mathrm{AUC}_{0 \text {-last }}(\mathrm{ng} / \mathrm{ml}$ per $\mathrm{h})$ & $9 \cdot 8$ & 1.6 & $21 \cdot 2$ & $6 \cdot 1$ & $116 \cdot 1$ & 11.9 & $58 \cdot 9$ & $12 \cdot 3$ & $45 \cdot 7$ & $5 \cdot 1$ \\
\hline$t_{\max }(\mathrm{h})$ & 0.7 & 0.3 & 8.0 & 0.0 & 1.3 & 0.7 & $7 \cdot 2$ & 1.8 & $1 \cdot 1$ & 0.5 \\
\hline
\end{tabular}

$\mathrm{C}_{\max }$, maximum concentration; $\mathrm{AUC}_{0 \text {-last }}$, area under the curve from 0 to the last sampling time; $t_{\operatorname{Max}}$, time to reach $\mathrm{C}_{\max }$.

until analysis. In all plasma samples, the following target compounds: CGA, CA, DHCA, FA, DHFA, apigenin and luteolin were analyzed in duplicate with and without enzymatic hydrolysis to detect free and conjugated form. Single phenol levels were evaluated by HPLC with electrochemical detector before and after enzymatic hydrolysis as described by Bugianesi et al. (2004) with slight modification. Briefly for free forms, $100 \mu \mathrm{l}$ ascorbic acid solution (1\%) was added to $0.5 \mathrm{ml}$ plasma and after vortexing and protein precipitation by $500 \mu \mathrm{l} 3 \mathrm{~mol} / \mathrm{l} \mathrm{HCl}-\mathrm{MeOH}(1: 1, \mathrm{v} / \mathrm{v})$, free phenols were extracted by adding $2 \mathrm{ml}$ ethyl acetate, followed by stirring and sonication $(2-3 \mathrm{~min}$ ) before centrifugation at $1700 \mathrm{~g}$ for $5 \mathrm{~min}$. The extraction procedure was repeated twice and the two organic layers were combined and evaporated. The residue was dissolved into $200 \mu \mathrm{l}$ mobile phase (phosphate buffer $\mathrm{pH} 2.8$ and methanol $(1: 1, \mathrm{v} / \mathrm{v}))$. Total phenols were evaluated after adding $100 \mu \mathrm{l}$ ascorbic acid solution (1\%), $100 \mu \mathrm{l} 0.2 \mathrm{M}$ acetic acid and $50 \mu \mathrm{l} \beta$-glucoronidase Type HP2 from Helix Pomatia (Sigma-Aldrich Srl, Milan, Italy). After incubating at $37^{\circ} \mathrm{C}$ for $1 \mathrm{~h}$ proteins were precipitated by adding $700 \mu \mathrm{l} 3 \mathrm{~mol} / \mathrm{l} \mathrm{HCl}-\mathrm{MeOH}(1: 1, \mathrm{v} / \mathrm{v})$, and total plasma phenols were extracted as previously described for free forms. Blank reagents were performed for free and total phenols forms evaluation. Quantitative analyses were performed on $50 \mu \mathrm{l}$ extract using an ESA-HPLC system (ESA, Chelmsford, MA, USA). The HPLC system used consisted of an ESA MODEL 540 refrigerated autoinjector $\left(4^{\circ} \mathrm{C}\right)$, an ESA MODEL 580 solvent delivery module with two pumps, an ESA 5600 eight-channels coulometric electrode array detector and the ESA coularray operating software which controlled all the equipment and carried out data processing. A Supelcosil LC-18 column $(25 \mathrm{~cm} \times 4.6 \mathrm{~mm}, 5 \mu \mathrm{m})$ with a Perisorb Supelguard LC-18 (Supelco, Milan, Italy) was used. Chromatography was performed at $30^{\circ} \mathrm{C}$, at a flow rate of $0.8 \mathrm{ml} / \mathrm{min}$ using the following solvent system: solvent $\mathrm{A}$, $0.02 \mathrm{~mol} \mathrm{NaH}_{2} \mathrm{PO}_{4}-\mathrm{H}_{2} \mathrm{O}$ adjusted to $\mathrm{pH} 2.8$ with $85 \%$ orthophosphoric acid; solvent $\mathrm{B}$, methanol. The linear gradient used consisted of $10 \%$ solvent $\mathrm{B}$, increasing to $30 \%$ over $7 \mathrm{~min}$ and to $33 \%$ over $28.5 \mathrm{~min}$, increasing to $45 \%$ over $19.5 \mathrm{~min}$, held for $8.5 \mathrm{~min}$ and reaching the final condition of $100 \% 24 \mathrm{~min}$ later, after that returning to $10 \%$ solvent $\mathrm{B}$ over 3 min and maintaining this condition for $4 \mathrm{~min}$. The flow rate of the eluent was constant at $0.8 \mathrm{ml} / \mathrm{min}$ and the setting potentials were 60, 120, 200, 340, 480, 620, 760 and $900 \mathrm{mV}$. Sample peaks were analyzed by matching target peaks with standard peaks on the basis of their retention time and on accuracy ratio between adjacent channels. The correlation coefficient for all calibration curves was $>0.99$. Spiked samples were processed and analyzed exactly as described earlier. Mean recovery of polyphenol standards added to plasma (n 3) was $>80-118 \%$ for CGA, DHCA, CA, DHFA and FA. The method showed a good reproducibility with coefficient of variation within days $<5 \%$ and between days $<9 \%$. Limits of detection were $2.5 \mathrm{ng} / \mathrm{ml}$ for CGA, DHCA, DHFA and FA and $2.7 \mathrm{ng} / \mathrm{ml}$ for CA.

\section{Statistics}

Data are given as the mean and standard deviation. Statistical analysis was performed using the non-parametric Friedman ANOVA test and the Wilcoxon matched pairs test. Differences were considered significant at $P<0 \cdot 05$. The computer program used was STATISTICA for Windows (release 4.5; StatSoft Inc., Vigonza PD, Italy).

\section{Results}

The composition of both raw and cooked artichoke heads is reported in Table 2. In order to evaluate the effect of domestic cooking on the content of polyphenols, the artichoke heads were analyzed before and after cooking, observing slight increase in CGA content. In addition, after cooking, the increasing of mono- and di-caffeoylquinic acids and the appearance of cynarin were observed. There were no differences in luteolin-glycoside and apigenin-glycoside content. The evaluation of polyphenol content in raw food has been widely studied and optimized on different food matrixes (Hertog et al. 1992). Several studies have shown the influence of heating treatments on antioxidant content and their stability (Brenes et al. 2002; Lombard et al. 2005; Innocenti et al. 2005; Rubinskiene et al. 2005; Budic-Leto et al. 2006).

Fig. 1 shows the plasma concentrations of target compounds after consumption of cooked artichoke heads. Maximum concentration of $6.4(\mathrm{SD} 1.8) \mathrm{ng} / \mathrm{ml}$ for CGA was reached after $1 \mathrm{~h}$ and declined until its disappearance within $2 \mathrm{~h}(P<0 \cdot 05)$.

Peak plasma concentrations of 19.5 (SD 6.9) $\mathrm{ng} / \mathrm{ml}$ for total CA were reached within $1 \mathrm{~h}$ while FA plasma concentrations showed a biphasic profile with 6.4 (SD 1.5) $\mathrm{ng} / \mathrm{ml}$ and 8.4 (SD 4.6) $\mathrm{ng} / \mathrm{ml}$ within $1 \mathrm{~h}$ and after $8 \mathrm{~h}$ respectively. We observed a significant $(P<0 \cdot 05)$ increase with respect to baseline for both CA and FA after administration of cooked head of artichoke during the entire experimental time. 

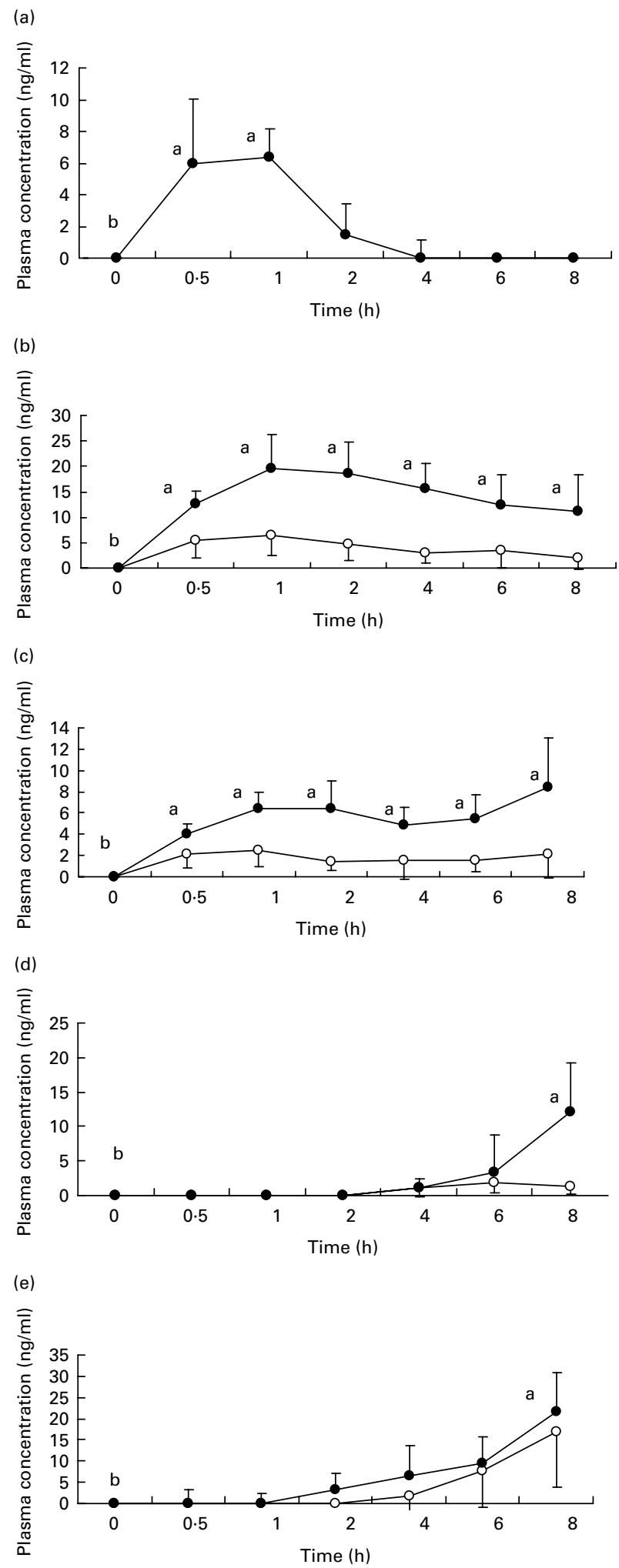

Fig. 1. Plasma concentrations of (a) chlorogenic acid; (b) caffeic acid; (c) ferulic acid; (d) dihydrocaffeic acid and (e) dihydroferulic acid after consumption of cooked Cyanara scolymus L. (cultivar Violetta di Provenza) heads. Values are means for five subjects with standard deviations shown by vertical bars. $\bigcirc$, plasma concentration of unconjugated polyphenols; $\bullet$, plasma concentration of conjugated plus uncongugated polyphenols. ${ }^{a, b}$ Wilcoxon test for comparison a $v . \mathrm{b}, P<0.05$.
Increase of DHCA and DHFA total levels was observed within $8 \mathrm{~h}$, to $12.1 \quad(\mathrm{SD} 7.2) \mathrm{ng} / \mathrm{ml} \quad(P<0.05)$ and 21.8 $($ SD 9.2$) \mathrm{ng} / \mathrm{ml}(P<0.05)$ respectively.

Representative chromatograms in Fig. 2 show the absorption profiles in one subject of target artichoke compounds at baseline and during the entire experimental time compared to specific standards. The unnamed peaks have to be considered unknown.

No circulating plasma levels of luteolin and apigenin were present.

\section{Discussion}

The current study shows that some artichoke compounds are able to cross the gastric barrier; our findings demonstrate that artichoke target compounds, after crossing the intestinal barrier, reach biologically effective concentrations in the bloodstream. It is well known that most classes of polyphenols are sufficiently absorbed to have the potential to exert biological effects. For example, quercetin after consumption of a meal containing onions, catechins after tea consumption, isoflavones after soya consumption and caffeic acid after drinking red wine, reach micromolar concentrations in blood (Abu Amsha Caccetta et al. 1996; Hollman et al. 1997; Maiani et al. 1997; Scalbert \& Williamson, 2000; Manach et al. 2002). Bioavailability depends on several endogenous and exogenous factors; the endogenous seem to be related to food matrix, size, chemical structure and ingested amount, the exogenous to digestive enzyme activities and bile excretion, and biotransformations related to liver, kidney, gastrointestinal epithelium and gut microbial flora.

The mean time to reach maximum concentration of 6.4 (SD 1.7) $\mathrm{ng} / \mathrm{ml}$ for CGA is surprising. Some authors have observed a fast absorption of CGA after oral administration of pure CGA and honeysuckle flower extract in rat (Lafay et al. 2006) and rabbit (Yang et al. 2004) respectively. Unmodified CGA also appears in human urine (Cremin et al. 2001; Olthof et al. 2001; Ito et al. 2005). On the contrary, other authors have failed to detect intact CGA in plasma after its administration as a pure compound in rats (Azuma et al. 2000) or after ingestion of coffee in human subjects (Nardini et al. 2002). The rapid plasma detection of CGA could be due to absorption of intact CGA through the stomach or the small intestine barrier. Lafay et al. (2006) have identified unchanged CGA in both the gastric vein and aorta showing that the stomach could be involved in CGA absorption in rats. Olthof et al. (2001) have indicated that one third of ingested CGA was absorbed in the small intestine in human subjects. Nevertheless, our low plasma CGA levels suggest that the largest portion of CGA and caffeoylquinic acids have undergone biotransformations.

CGA and caffeoylquinic acid hydrolysis, and their metabolites release, could begin in the small intestine. In addition, Andreasen et al. (2001) have shown that esterases with activity similar to esters of the major dietary hydroxycinnamates are distributed throughout the intestinal tract of mammals.

The observed CA and FA plasma levels could originate from hydrolysis of both CGA and caffeoylquinic acids, that represent the predominant polyphenol forms in the test meal. 

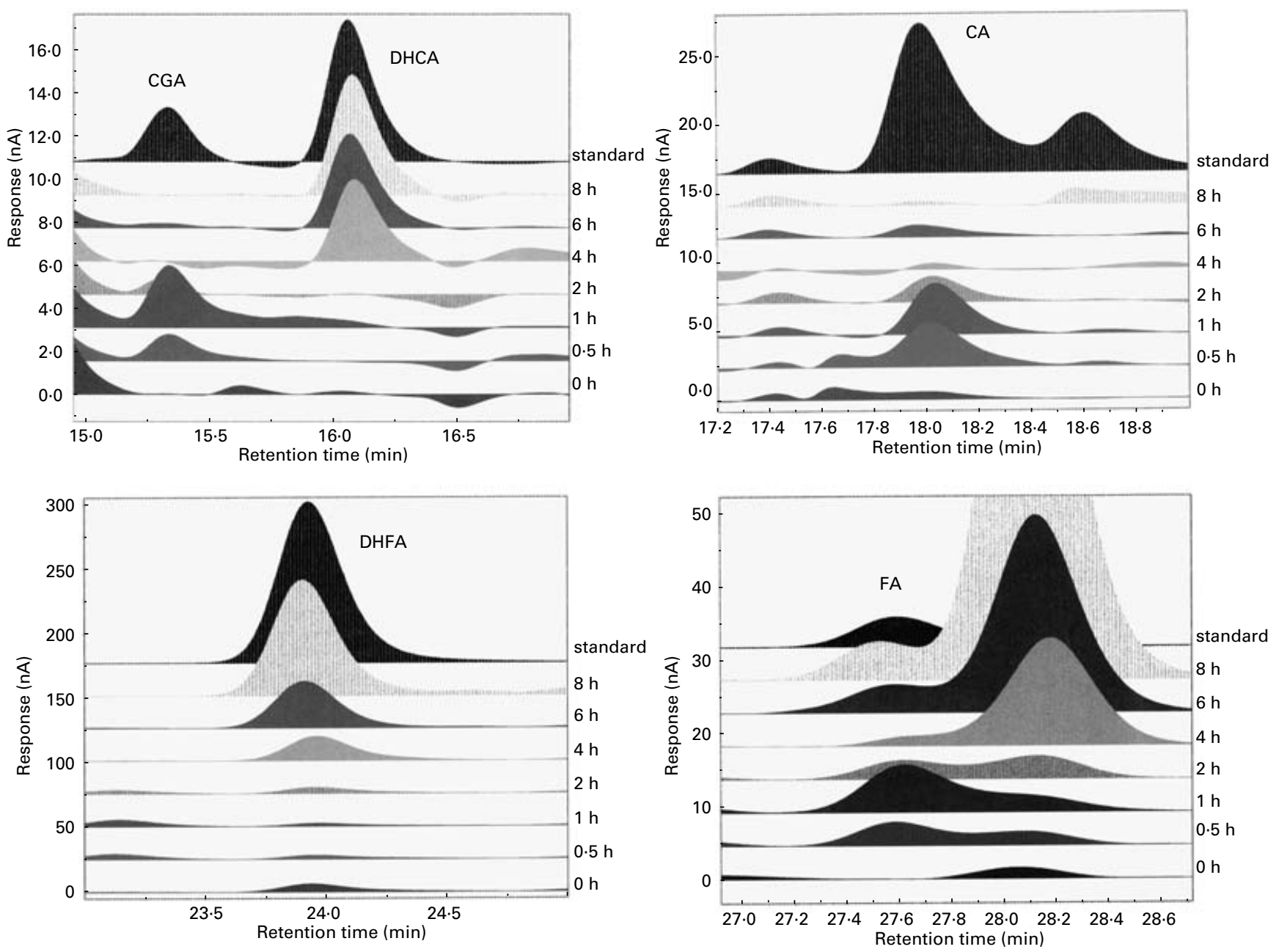

Fig. 2. Representative chromatograms of the absorption profiles in one subject of target artichoke compounds (CGA, chlorogenic acid; DHCA, dihydrocaffeic acid; CA, caffeic acid; DHFA, dihydroferulic acid; FA, ferulic acid) at baseline and during the entire experimental time compared to specific standards. The unnamed peaks have to be considered unknown.

Free plasma levels were low with respect to total forms of CA and FA (Wittemer et al. 2005); CA and FA conjugates reached the maximum concentration within $1.5 \mathrm{~h}$. This result seems to suggest that the hydrolysis of active compounds of artichoke heads should have partially occurred in the small intestine (Lafay et al. 2006; Azuma et al. 2000; Nardini et al. 2002).

On reaching the large intestine, unchanged CGA is hydrolyzed by colon enzymes into various aromatic acid metabolites before absorption (m-coumaric acid, derivatives of phenylpropionic and benzoic acids; Booth et al. 1957; Rechner et al. 2001a). Several metabolites have been identified after ingestion of CGA or CA, namely FA, isoFA, DHFA and vanillic acid in human subjects (Rechner et al. 2001b).

The colonic microflora has been designated as the major metabolic site for the reactions of the cleavage of ester or glycoside bonds, releasing free hydroxycinnamic acids (Plumb et al. 1999; Couteau et al. 2001; Rechner et al. 2001a).

$\mathrm{CA}$, released by gut microflora, was absorbed and transported to the liver for $o$-methylation to FA (Masri et al. 1964; Scheline, 1991; Gumbinger et al. 1993; Moridani et al. 2001). Nevertheless the gut microflora could be able to catalyze the $o$-methylation of CA to yield FA and isoFA (Chesson et al. 1999).

From our findings, the mean time to reach maximum concentration for DHCA and DHFA was 6-8 h (Wittemer et al. 2005). The decrease of CA levels within $6 \mathrm{~h}$ and the simultaneous increase of DHCA and DHFA in the bloodstream seem to suggest that CA, released after hydrolysing CGA and caffeoylquinic acids by microflora, was metabolized into DHCA before absorption (Peppercorn \& Goldman, 1971). This result could indicate the gut as probable and predominant location of hydroxycinnamate esters metabolism (Andreasen et al. 2001, Couteau et al. 2001).

Absorbed DHCA could be methylated into DHFA and then dehydrogenated into FA in the liver (Moridani et al. 2001). Nevertheless our results indicate that the same reaction mechanisms could take place in the large intestine, particularly dehydrogenation by the colon flora and methylation inside the colon wall. This may contribute to explaining the biphasic concentration profile observed in our samples for total FA.

Moridani et al. (2002) have reported that CA and DHCA biotransforming reactions, such as $o$-methylation, GSH conjugation, hydrogenation and dehydrogenation, take places in the 
liver catalyzed by $\mathrm{P} 450$ cytocrome. On the other hand, some researchers suggest that $\mathrm{CA}$ and DHCA methylation into FA and DHFA respectively may occur in the gut (Booth et al. 1957; Chesson et al. 1999; Ranganathan \& Ramasarma, 1974). In both rats and human subjects, dietary plant phenolics can undergo metabolism to form reactive intermediates by catechol-o-methyltransferases present in the liver, also in the kidneys and gastrointestinal tracts both stomach and intestine (Nissinen et al. 1988; Schultz \& Nissinen, 1989; Mannisto et al. 1992).

The lack of circulating levels of luteolin and apigenin could be due to their low concentrations in the test meal administered. Several factors may explain the variability of the polyphenols bioavailability, such as the food matrix or background diet. In addition inter-individual variations are also important, because some people might have different levels of metabolizing enzymes or transporters, enabling more efficient absorption of bioactive compounds.

In conclusion, our study shows for the first time the absorption pathways of hydroxycinnamic acids after consumption of edible cooked artichoke in human subjects. These results should be supported by other investigations to confirm the biological activity of cooked artichoke in human subjects and to better understand the mechanism of food phenolic metabolism. With the current conflict existing in the understanding of the metabolism of hydroxycinnamic acids further research is required.

\section{Acknowledgements}

We thank Dr Sergio Corelli for his medical assistance during the study, Ms Lara Palomba for her assistance during the preparation of the paper, Dr Federica Intorre for statistical analyses and Dr Angela Cardinali for her contribution to the study. Finally, thanks are also given to all study participants. This study was supported by MiPAF.

\section{References}

Abu Amsha Caccetta RA, Croft KD, Puddey IB, Proudfoot JM \& Beilin LJ (1996) Phenolic content of various beverages determines the extent of inhibition of human serum and low density lipoprotein oxidation in vitro: identification and mechanism of action of some cinnamic acid derivatives from red wine. Clin Sci 91, $449-458$.

Adzet T, Camarasa J \& Laguna JC (1987) Hepatoprotective activity of polyphenolic compounds from Cynara Scolymus against CCl4 toxicity in isolated rat hepatocytes. J Nat Prod 50, 612-617.

Andreasen MF, Kroon PA, Williamson G \& Garcia-Conesa MT (2001) Esterase activity able to hydrolyze dietary antioxidant hydroxycinnamates is distributed along the intestine of mammals. J Agric Food Chem 49, 5679-5684.

Azuma K, Ippoushi K, Nakayama M, Ito H, Higashio H \& Terao J (2000) Absorption of chlorogenic acid and caffeic acid in rat after oral administration. J Agric Food Chem 48, 5496-5500.

Booth AN, Emerson OH, Jones FT \& Deeds F (1957) Urinary metabolites of caffeic and chlorogenic acids. J Biol Chem 229, 51-59.

Brenes M, García A, Dobarganes MC, Velasco J \& Romero C (2002) Influence of thermal treatments simulating cooking processes on the polyphenol content in virgin olive oil. J Agric Food Chem 50, 5962-5967.
Bruneton J (1995) Pharmacognosy Phytochemistry Medicinal Plants. Lavoisier Publishing: Secaucus, NY, pp. 218-219.

Budic-Leto I, Lovric T, Kljusuric JG, Pezo I \& Vrhovsek U (2006) Anthocyanin composition of the red wine Babic affected by maceration treatment. Eur Food Res Technol 222, 397-402.

Bugianesi R, Salucci M, Leonardi C, Ferracane R, Catasta G, Azzini E \& Maiani G (2004) Effect of domestic cooking on human bioavailability of naringenin, chlorogenic acid, lycopene and B-carotene in cherry tomatoes. Eur J Nutr 43, 360-366.

Chesson A, Provan GJ, Russell WR, Scobbie L, Richardson AJ \& Stewart C (1999) Hydroxycinnamic acids in the digestive tract of livestock and humans. J Sci Food Agric 79, 373-378.

Couteau D, McCartney AL, Gibson GR, Williamson G \& Faulds CB (2001) Isolation and characterization of human colonic bacteria able to hydrolyse chlorogenic acid. J Appl Microbiol 90, 873-881.

Cremin P, Kasim-Karakas S \& Waterhouse AL (2001) LC/ES-MS detection of hydroxycinnamates in human plasma and urine. $J$ Agric Food Chem 49, 1747-1750.

Di Venere D, Linsalata V, Calabrese N, Pieralice M, Bianco VV \& Lattanzio V (2005) Morphological and biochemical changes during development of artichoke buds. Acta Hort 681, 437-443, (ISHS).

Gebhardt R (1997) Antioxidative and protective properties of extract from leaves of the artichoke (Cynara scolymus L.) against hydroperoxide-induced oxidative stress in cultured rat hepatocytes. Toxicol Appl Pharm 144, 279-286.

Gebhardt R (1998) Inhibition of cholesterol biosyntesis in primary cultured rat hepatocytes by artichoke (Cynara scolymus L.) extracts. J Pharmacol Exp Ther 286, 1122-1128.

Gebhardt R (2002) Inhibition of cholesterol biosyntesis HepG2 cells by artichoke extracts is reinforced by glucosidase pretreatment. Phytother Res 16, 368-372.

Gumbinger HG, Vahlensieck U \& Winterhoff H (1993) Metabolism of caffeic acid in the isolated perfused rat liver. Planta Med 59, 491-493.

Hertog MGL, Hollman CH \& Venema DP (1992) Optimization of quantitative HPLC determination of potentially anticarcenogenic flavonoids in vegetables and fruit. J Agric Food Chem 40, 1591-1598.

Hollman PC, van der Gaag M, Mengelers MJ, van Trijp JM, de Vries JH \& Katan MB (1996) Absorption and disposition kinetics of the dietary antioxidant quercetin in man. Free Radic Biol Med 21, 703-707.

Hollman PC, van Trijp JM, Buysman MN, van der Gaag MS, Mengelers MJ, de Vries JH \& Katan MB (1997) Relative bioavailability of the antioxidant flavonoid quercetin from various food in man. FEBS Lett 418, 152-156.

Innocenti M, Gallori S, Giaccherini C, Ieri F, Vincieri FF \& Mulinacci N (2005) Evaluation of the phenolic content in the aerial parts of different varieties of Cichorium intybus L. J Agric Food Chem 53, 6497-6502.

Ito H, Gonthier MP, Manach C, Morand C, Mennen L, Rémésy C \& Scalbert A (2005) Polyphenol levels in human urine after intake of six different polyphenol-rich beverages. Br J Nutr 94, 500-509.

Kirchhoff R, Beckers C, Kirchhoff GM, Trinczek-Gartner H, Petrowitz O \& Reimann HJ (1994) Increase in choleresis by means of artichoke extract. Results of a randomized placebo-controlled double-blind study. Phytomedicine 1, 107-115.

Kraft K (1997) Artichoke leaf extract. Recent findings reflecting effects on lipid metabolism, liver, and gastrointestinal tracts. Phytomedicine 4, 369-378.

Lafay S, Gil-Izquierdo A, Manach C, Morand C, Besson C \& Scalbert A (2006) Chlorogenic acid is absorbed in its intact form in the stomach of rats. J Nutr 136, 1192-1197.

Lattanzio V \& Van Sumere CF (1987) Changes in phenolics during development and cold storage of artichoke (Cynara scolymus L.). Food Chemistry 24, 37-50. 
Lombard K, Peffley E, Geoffriau E, Thompson L \& Herring A (2005) Quercetin in onion (Allium cepa L.) after heat-treatment simulating home preparation. J Food Compost Anal 18, 571-581.

Lopez-Molina D, Navarro-Martinez MD, Melgarejo FR, Hiner ANP, Chazarra S \& Rodríguez-Lopez JN (2005) Molecular properties and prebiotic effect of inulin obtained from artichoke (Cynara scolymus L.). Phytochemistry 66, 1476-1484.

McAnlis GT, McEneny J, Pearce J \& Young IS (1999) Absorption and antioxidant effects of quercetin from onions in man. Eur $J$ Clin Nutr 53, 92-96.

Maiani G, Serafini M, Salucci M, Azzini E \& Ferro-Luzzi (1997) Application of a new high-performance liquid chromatographic method for measuring selected polyphenols in human plasma. $J$ Chrom B Biomed Sci Appl 692, 311-317.

Manach C, Scalbert A, Morand C, Rémésy C \& Jiménez L (2004) Polyphenols: food sources and bioavailability. Am J Clin Nutr 79, 727-747.

Manach C, Williamson G, Morand C, Scalbert A \& Rémésy C (2005) Bioavailability and bioefficacy of polyphenols in humans. I. Review of 97 bioavailability studies. Am J Clin Nutr. 81, 230S-242S.

Mannisto PT, Tuomainen P \& Tuominen RK (1992) Different in vivo properties of three new inhibitors of catechol-O-methyltransferase in the rat. Br J Pharmacol 105, 569-574.

Masri MS, Robbins DJ, Emerson OH \& De Eds F (1964) Selective para- or meta- $O$-methylation with catechol. $O$-methyl transferase from rat liver. Nature 202, 878-879.

Miccadei S, Bugianesi R, Di Venere D, Cardinali A, Linsalata V, Foddai MS \& Maiani G (2004) Efficacia protettiva da danno ossidativi di frazioni polifenoliche da Cynara Scolymus in epatociti di ratto. Italus Hortus 11, 86-89.

Moridani MY, Scobie H, Jamshidzadeh A, Salehi P \& O'Brien PJ (2001) Caffeic acid, chlorogenic acid, and dihydrocaffeic acid metabolism: glutathione conjugate formation. Drug Metab Dispos 29, $1432-1439$.

Moridani MY, Scobie H \& O'Brien PJ (2002) Metabolism of caffeic acid by isolated rat hepatocytes and subcellular fractions. Toxicol Lett 133, 141-151.

Nardini M, Cirillo E, Natella F \& Scaccini C (2002) Absorption of phenolic acids in humans after coffee consumption. J Agric Food Chem 50, 5735-5741.

National Institute for Food and Nutrition Research (INRAN) (2000) Food Composition Tables. Rome, Italy: EDRA-Medical Publishing New Media.

Nissinen E, Linden IB, Schultz E, Kaakkola S, Mannisto PT \& Pohto P (1988) Inhibition of catechol-O-methyltransferase activity by two novel disubstituted catechols in the rat. Eur J Pharmacol 153, 263-269.

Olthof MR, Hollman PCH \& Katan MB (2001) Chlorogenic and caffeic acid are absorbed in humans. J Nutr 131, 66-71.

Peppercorn MA \& Goldman P (1971) Caffeic acid metabolism by bacteria of the human gastrointestinal tract. $J$ Bacteriol 108, 996-1000.

Plumb GW, Garcia-Conesa MT, Kroon PA, Rodhes M, Ridley S \& Williamson G (1999) Metabolism of chlorogenic acid by human plasma, liver, intestine and gut microflora. J Sci Food Agric 79, 390-392.

Ranganathan S \& Ramasarma T (1974) The metabolism of phenolic acids in the rat. Biochem $J$ 140, 517-522.

Rechner AR, Spencer JPE, Kuhnle G, Hahn U \& Rice-Evans CA (2001a) Novel biomarkers of the metabolism of caffeic acid derivatives in vivo. Free Rad Biol Med 30, 1213-1222.

Rechner AR, Pannala AS \& Rice-Evans CA (2001b) Caffeic acid derivatives in artichoke extract are metabolised to phenolic acids in vivo. Free Rad Res 35, 195-202.

Roberfroid MB, Van Loo JA \& Gibson GR (1998) The bifidogenic nature of chicory inulin and its hydrolysis products. $J$ Nutr $\mathbf{1 2 8}$, $11-19$.

Rubinskiene M, Viskelis P, Jasutiene I, Viskeliene R \& Bobinas C (2005) Impact of various factors on the composition and stability of black currant anthocyanins. Food Res Int 38, 867-871.

Scalbert A \& Williamson G (2000) Dietary intake and bioavailability of polyphenols. J Nutr 130, 2073S-2085S.

Scheline RR (1991) Metabolism of acids, lactones and esters. In Handbook of mammalian metabolism of plant compounds, pp. 168-170 Boca Ranton, USA: CRC Press.

Schultz E \& Nissinen E (1989) Inhibition of rat liver and duodenum soluble catechol-O-methyltransferase by a tight-binding inhibitor OR-462. Biochem Pharmacol 38, 3953-3956.

Schütz K, Kammerer D, Carle R \& Schieber A (2004) Identification and quantification of caffeoylquinic acids and flavonoids from artichoke (Cynara scolymus L.) heads, juice, and pomace by HPLC-DAD-ESI/MS. J Agric Food Chem 52, 4090-4096.

Shimoda H, Ninomiya $K$, Nishida $N$, Yoshino $T$, Morikawa $T$, Matsuda H \& Yoshikawa M (2003) Anti-hyperlipidemic sesquiterpenes and new sesquiterpene glycosides from the leaves of artichoke (Cynara scolymus L.): structure requirement and mode of action. Bioorg Med Chem Lett 13, 223-228.

Speroni E, Cervellati R, Govoni P, Guizzardi S, Renzulli C \& Guerra MC (2003) Efficacy of different Cynara scolymus preparations on liver complaints. J Ethnopharm 86, 203-211.

Wang M, Simon JE, Aviles IF, He K, Zheng QY \& Tadmor Y (2003) Analysis of antioxidative phenolic compounds in artichoke (Cynara scolymus L.). J Agric Food Chem 51, 601-608.

Wittemer SM, Ploch M, Windeck T, Müller SC, Drewelow B, Derendorf H \& Veit M (2005) Bioavailability and pharmacokinetics of caffeoylquinic acids and flavonoids after oral administration of artichoke leaf extracts in humans. Phytomedicine 12, 28-38.

Yang H, Yuan B, Li L, Chen H \& Li F (2004) HPLC determination and pharmacokinetics of chlorogenic acid in rabbit plasma after an oral dose of Flos Lonicerae extract. J Chromatogr Sci 42, $173-176$

Zapolska-Downar D, Zapolski-Downar A, Naruszewicz M, Siennicka A, Krasnodębska B \& Kolodziej B (2002) Protective properties of artichoke (Cynara scolymus) against ossidative stress induced in cultured endothelial cells and monocytes. Life Sci 71, 2897-2908.

Zhu X \& Zhang H (2004) Phenolic compounds from the leaf extract of artichoke (Cynara scolymus L.) and their antimicrobial activities. J Agric Food Chem 52, 7272-7278. 